\title{
MENGANALISIS DAN MELIHAT HUBUNGAN ANTARA FAKTOR - FAKTOR YANG MEMPENGARUHI PEMILIHAN PRODUK MIE INSTAN STUDI KASUS : MAHASISWA JURUSAN MATEMATIKA FMIPA UNTAD
}

\author{
${ }^{1}$ N.Rahmayuni, ${ }^{2}$ Rais, dan ${ }^{3}$ I.T. Utami \\ 1,2,3Program Studi Matematika Jurusan Matematika FMIPA Universitas Tadulako \\ Jalan Soekarno-Hatta Km. 09 Tondo, Palu 94118, Indonesia. \\ 1yuny.twinz@gmail.com,2rais76untad@yahoo.co.id, ${ }^{3}$ triutammi.iut@gmail.com
}

\begin{abstract}
Fast food is a ease and practical in meeting the needs of food, one of them is instant noodles many chosen by the community. This study research regarding consumers in an election products instant noodles to be consumed. The analytical method used in this research is the factor analysis, to describe consumer behavior towards an influential factor in the selection of instant noodles by the students of the Faculty of Science and Mathematics and to know the most dominant variable shaping it. In addition, this study also uses the correspondence analysis to look at the linkages and patterns of relationships among factors that influence the selection of instant noodle products. Factors that influence the election of the instant noodlesproducts namely the quality of noodles, quantity noodles, flavoe dan seasoning, nutrients, price packaging, promotion and ease ofacquiring. From the results of a factor analysis obtained the external factor noodles a factor most dominant for variables Indomie and Sarimi, because it has the value of eigen largest. While to the factors of product quality noodles is a most dominant for variables sarimi, because it has the largest of eigen value. Then, the results of correspondences analysis indicate that Indomie and Supermi instant noodles have a very good quality of flavors, seasonings and noodles, because they have a pattern of relationships among factors that influence the selection of instant noodle products. While Sarimi instant noodle have a mediocre quality of flavors, seasonings, and noodles.
\end{abstract}

Keywords: Choosing Instant Noodles Products, Correspondence Analysis, Eigen Value, Factor Analys is, Instant Noodles,

\begin{abstract}
ABSTRAK
Makanan cepat saji merupakan suatu kemudahan dan kepraktisan dalam pemenuhan kebutuhan pangan, salah satunya adalah mie instan yang banyak dipilh oleh masyarakat. Penelitian ini akan meneliti tentang pertimbangan konsumen dalam pemilihan produk mie instan untuk dikonsumsi. Metode analisis yang digunakan pada penelitian ini adalah analisis faktor untuk mendeskripsikan perilaku konsumen terhadap faktor yang berpengaruh dalam pemilihan produk mie instan di kalangan mahasiswa Matematika di FMIPA dan mengetahui variabel yang paling dominan membentuknya. Selain itu, penelitian ini juga menggunakan metode analisis korespondensi untuk melihat keterkaitan dan pola hubungan antara faktor-faktor yang mempengaruhi pemilihan produk mie instan. Faktor-faktor yang berpengaruh dalam pemilihan produk mie instan yaitu kualitas mie, kuantitas mie, rasa dan bumbu, nutrisi, harga, kemasan, promosi serta kemudahan memperoleh. Dari hasil analisis faktor diperoleh faktor
\end{abstract}


eksternal mie merupakan faktor paling dominan untuk variabel Indomie dan Sarimi, karena memiliki nilai eigen terbesar. Sedangkan untuk faktor kualitas produk mie merupakan faktor paling dominan untuk variabel sarimi, karena memiliki nilai eigen terbesar. Kemudian dari hasil analisis korespondensi diperoleh produk mie instan Indomie dan Supermi memiliki rasa dan bumbu serta kualitas mie yang sangat baik, karena mempunyai pola hubungan antara faktor-faktor yang mempengaruhi pemilihan produk mie instan. Sedangkan untuk produk mie instan sarimi memiliki rasa dan bumbu serta kualitas mie biasa saja.

Kata kunci: Pemilihan Produk Mie Instan, Analisis Korespondensi, Nilai Eigen, Analisis Faktor, Mie Instan.

\section{PENDAHULUAN}

\subsection{Latar Belakang Penelitian}

Kehidupan masyarakat yang semakin modern menjadikan pola makan dan kebutuhan yang berbeda. Makanan yang cepat saji merupakan suatu kemudahan dan kepraktisan dalam pemenuhan kebutuhan pangan. Salah satu makanan cepat saji yang praktis dan banyak dipilih oleh masyarakat adalah mie instan.

Menurut Nugraha Pukuh (2007) produk mie instan termasuk makanan yang sangat digemari masyarakat Indonesia khususnya untuk dikalangan pelajar dan mahasiswa mandiri yang jauh dari orang tua dan tinggal di kos-kosan. Rasanya yang enak, ekonomis, dan praktis merupakan alasan yang umum mendasari kebanyakan konsumen mie instan di Indonesia rela mengeluarkan isi kantongnya untuk membeli produk ini dengan berbagai rasa yang mereka inginkan.

Sebelumnya penelitian ini telah dilakukan oleh Nugraha Pukuh tentang "Gambaran perbandian persepsi konsumen terhadap produk mie instan merek indomie, supermi dan mie sedaap (studi kasus konsumen mie instan indomie, supermi dan mie sedaap di Mal Ambasador tahun 2007)" dengan mengunakan metode analisis deskriptif, analisis multi dimensional scaling (MDS) dan analisis korespondensi sederhana. Penelitian ini bertujuan untuk mengetahui pertimbangan konsumen dalam memilih merek mie instan, bagaimana posisi Indomie, Supermi, dan Mie Sedaap berdasarkan persepsi konsumen, serta ciri khas dan keinginan konsumen untuk mengkonsumsi kembali ketiga produk tersebut.

Dalam penelitian ini akan meneliti tentang pertimbangan konsumen dalam pemilihan produk mie instan untuk dikonsumsi. Sehingga penelitian ini akan menggunakan metode analisis faktor untuk mengetahui faktor-faktor yang berpengaruh dalam pemilihan produk mie instan. Selain itu penelitian ini juga menggunakan metode analisis korespondensi untuk melihat keterkaitan dan pola hubungan antara faktor-faktor yang mempengaruhi pemilihan produk mie instan. 


\subsection{Rumusan Masalah}

Berdasarkan latar belakang di atas, maka pokok permasalahan yang dikemukakan dalam penelitian ini adalah :

1. Bagaimana perilaku konsumen dan faktor-faktor apa saja yang mempengaruhi konsumen dalam pemilihan produk mie instan serta variabel-variabel apa yang membentuknya?

2. Faktor manakah yang paling berpengaruh pada konsumen dalam pemilihan produk mie instan?

3. Apakah ada keterkaitan antara faktor-faktor yang mempengaruhi pemilihan produk mie instan?

4. Bagaimana pola hubungan antara faktor-faktor yang mempengaruhi pemilihan produk mie instan?

\subsection{Tujuan Penelitian}

Penelitian ini bertujuan untuk:

1. Mendeskripsikan perilaku konsumen dan mengetahui faktor-faktor apa yang mempengaruhi konsumen dalam pemilihan produk mie instan mie serta variabelvariabel apa yang membentuknya.

2. Mengetahui faktor yang paling berpengaruh pada konsumen dalam pemilihan produk mie instan.

3. Mengetahui ada tidaknya keterkaitan antara faktor-faktor yang mempengaruhi pemilihan produk mie instan.

4. Mengetahui pola hubungan antara faktor-faktor yang mempengaruhi pemilihan produk mie instan.

\subsection{Batasan Masalah}

Batasan masalah dalam penelitian ini yaitu penulis tidak mengambil semua produk mie instan yang beredar di pasaran, melainkan hanya mengambil tiga merek mie instan saja. Ketiga produk yang dipilih adalah Indomie, Supermi dan Sarimi karena ketiga merek ini sudah cukup populer di masyarakat dan memiliki tingkat pemasaran yang besar di Indonesia. Produksi mie instan ini juga memiliki produsen yang sama yaitu PT. Indofood Sukses Makmur Tbk. Variabel penelitian ini yaitu kualitas mie, kuantitas mie, rasa dan bumbu, nutrisi, kemasan, harga, promosi serta kemudahan dalam mendapatkan mie instan.

\subsection{Manfaat Penelitian}

Manfaat yang ingin diperoleh dari penelitian ini adalah :

1. Sebagai informasi bagi mahasiswa untuk menambah pengetahuan tentang analisis faktor dan analisis korespondensi dalam ilmu statistik serta wawasan bagi penulis tentang tanggapan terhadap beberapa produk mie instan. 
2. Memberikan masukan bagi produsen mie instan untuk dijadikan sebagai referensi dalam peningkatan kualitas dan strategi pemasaran.

\section{METODE PENELITIAN}

\subsection{Jenis Data Dan Variabel Penelitian}

Jenis data yang digunakan dalam penelitian ini adalah data kualitatifyang berasal dari data kuesioner yang ditranformasikan menjadi data kuantitatif. Penelitian ini berada dalam pemilihan produk merek mie instan yang paling digemari. Variabel yang digunakan untuk variabel $(Y)$ terdiri dari Indomie $\left(Y_{1}\right)$, Supermi $\left(Y_{2}\right)$ dan Sarimi $\left(Y_{3}\right)$. Sedangkan untuk variabel $(\mathrm{X})$ terdiri dari kualitas mie $\left(\mathrm{X}_{1}\right)$, kuantitas mie $\left(\mathrm{X}_{2}\right)$, rasa dan bumbu $\left(\mathrm{X}_{3}\right)$, nutrisi $\left(\mathrm{X}_{4}\right)$, harga $\left(\mathrm{X}_{5}\right)$, kemasan $\left(\mathrm{X}_{6}\right)$, harga, promosi $\left(\mathrm{X}_{7}\right)$ serta kemudahan mendapat $\left(\mathrm{X}_{8}\right)$.

\subsection{Polulasi dan Sampel Penelitian}

Populasi dalam penelitian ini adalah mahasiswa Jurusan Matematika angkatan 2012 2015 yang berjum lah 203 mahasiswa. Teknik pengam bilan sampel penelitian menggunakan rumus sebagai berikut: (Taro Yamane atau Slovin dalam Riduwan dan Kuncoro, E.A.,2007).

$$
n=\frac{N}{N d^{2}+1}
$$

dimana :

$n=$ Banyaknya Sampel

$N=$ Banyaknya Populasi

$d=$ Presisi (ditetapkan 5\% dengan tingkat kepercayaan 95\%)

Banyaknya sampel yang diperoleh berdasarkan persamaan (1) adalah 135 mahasiswa.

\subsection{Prosedur Pengolahan data}

Prosedur pengolahan data pada penelitian ini adalah Uji Validitas dan Uji Reliabelitas, jika data tidak valid dan reliabel maka pertanyaan yang tidak valid dan reliabel dihilangkan dalam kuesiner, jika sudah valid dan reliabel maka dapat dilanjutkan, analisis faktor, analisis korespondensi, kesimpulan.

\section{HASIL DAN PEMBAHASAN}

\subsection{Hasil Penelitian}

\subsubsection{Uji Validitas}

Pengujian validitas butir pertayaan dilakukan secara terpisah untuk masing masing kelom pok mie instan menggunakan korelasi Pearson Product Moment. Setiap pertanyaan dikatakan valid apabila $t_{\text {hitung }}>t_{\text {tabel }}$. Hasil uji validitas untuk masingmasing mie instan didapatkan melalui Program SPSSdiperoleh bahwa semua pertanyaan adalah valid karena semua nilai $t_{\text {hitung }}$ lebih besar dari nilai $t_{\text {tabel }}$, dengan 
nilai $t_{\text {tabel }}=t_{\frac{1}{2} \alpha ; n-2}=t_{0,025 ; 133}=1,98$, dengan $\alpha=0,05$ dan derajat kebabasan ( $\left.\mathrm{dk}\right)$ $n-2$ yaitu 133 .

\subsubsection{Uji Reliabitas}

Uji reliabilitas hanya dilakukan pada pertanyaan yang valid. Pengujian reliabilitas dilakukan secara terpisah untuk masing-masing kelompok mie instan. Metode yang digunakan untuk melakukan pengujian reliabilitas yaitu metode alpha $\operatorname{cronbach}(\alpha)$ dan apabila $\alpha<0,6$ maka pertanyaan tersebut dianggap tidak valid dan reliabel.Hasil uji reliabilitas untuk masing-masing mie instan didapatkan melalui Program SPSSdiperoleh bahwa nilai alpha cronbach $(\alpha)$ untuk kelompok Indomie sebesar 0,632. Kemudian untuk kelompok Supermi sebesar 0,646 dan kelompok Sarimi sebesar 0,614 . Sehingga nilai alpha cronbach $(\alpha)$ ketiga merek mie instan tersebut lebih dari 0,6 yang berarti pertanyaan dalam kuesioner adalah reliabel.

\subsection{Analisis Faktor}

\subsubsection{Uji Kelayakan faktor}

1. Uji KMO (Kaieser-Mayer-Olkin)

Tabel 1 : Hasil KMO dan Bartlett's Test Indomie

\begin{tabular}{|l|l|c|c|c|}
\hline \multicolumn{2}{|l|}{ KMO and Bartlett's Test } & Indomie & Supermie & Sarimi \\
\hline $\begin{array}{l}\text { Kaiser-Meyer-Olkin Measure of } \\
\text { Sampling Adequacy. }\end{array}$ &, 746 &, 688 &, 728 \\
\hline $\begin{array}{l}\text { Bartlett's Test } \\
\text { of Sphericity }\end{array}$ & Approx. Chi-Square & 107,735 & 119,125 & 114,956 \\
\cline { 2 - 5 } & Df & 28 & 28 & 28 \\
\cline { 2 - 5 } & Sig. &, 000 &, 000 &, 000 \\
\hline
\end{tabular}

Dari ketiga tabel di atas dapat dilihat bahwa semua nilai KMO untuk Indomie, Supermi dan Sarimi lebih besar dari 0,5 yang berarti dapat dilakukan analisis lebih lanjut.

\section{Uji MSA (Measure of Sampling Adequacty)}

Tabel 2 : Hasil Uji MSA Indomie

\begin{tabular}{|l|c|c|c|}
\hline \multicolumn{1}{|c|}{ Variabel Uji MSA } & Indomie & Supermi & Sarimi \\
\hline Kualitas Mie & 0,707 & 0,649 & 0,723 \\
\hline Kuantitas Mie & 0,757 & 0,770 & 0,510 \\
\hline Rasa dan Bumbu & 0,782 & 0,737 & 0,732 \\
\hline Nutrisi & 0,782 & 0,715 & 0,687 \\
\hline Harga & 0,714 & 0,646 & 0,743 \\
\hline Kemasan & 0,753 & 0,715 & 0,759 \\
\hline Promosi & 0,750 & 0,604 & 0,712 \\
\hline
\end{tabular}




\begin{tabular}{|l|l|l|l|}
\hline Kemudahan Memperoleh & 0,759 & 0,694 & 0,733 \\
\hline
\end{tabular}

Dari Tabel diatas dapat dilihat bahwa semua nilai MSA yang dihasilkan lebih besar dari 0,5 sehingga kedelapan variabel Indomie, Supermi dan Sarimi dapat dianalisis lebih lanjut.

\subsubsection{Bentuk Matriks}

1. matriks korelasi antar variable indomie sebagai berikut:

$\left[\begin{array}{cccccccc}1 & 0,057 & 0,227 & 0,099 & 0,058 & 0,233 & 0,070 & 0,182 \\ 0,057 & 1 & 0,281 & 0,040 & 0,180 & 0,055 & 0,203 & 0,226 \\ 0,227 & 0,281 & 1 & 0,102 & 0,255 & 0,306 & 0,168 & 0,354 \\ 0,099 & 0,040 & 0,102 & 1 & 0,162 & 0,092 & 0,059 & 0,121 \\ 0,058 & 0,180 & 0,255 & 0,162 & 1 & 0,242 & 0,097 & 0,390 \\ 0,233 & 0,055 & 0,306 & 0,092 & 0,242 & 1 & 0,340 & 0,242 \\ 0,070 & 0,203 & 0,168 & 0,059 & 0,327 & 0,130 & 1 & 0,219 \\ 0,182 & 0,226 & 0,354 & 0,121 & 0,390 & 0,242 & 0,219 & 1\end{array}\right]$

2. matriks korelasi antar variabel sebagai berikut:

$\left[\begin{array}{cccccccc}1 & 0,106 & 0,261 & 0,247 & 0,075 & 0,204 & 0,093 & 0,239 \\ 0,106 & 1 & 0,241 & 0,073 & 0,280 & 0,063 & 0,156 & 0,239 \\ 0,261 & 0,214 & 1 & 0,197 & 0,345 & 0,311 & 0,137 & 0,232 \\ 0,247 & 0,073 & 0,197 & 1 & 0,212 & 0,075 & 0,063 & 0,160 \\ 0,075 & 0,280 & 0,345 & 0,212 & 1 & 0,175 & 0,323 & 0,356 \\ 0,204 & 0,063 & 0,311 & 0,075 & 0,175 & 1 & 0,085 & 0,258 \\ 0,093 & 0,156 & 0,137 & 0,063 & 0,323 & 0,085 & 1 & 0,053 \\ 0,239 & 0,239 & 0,232 & 0,160 & 0,356 & 0,285 & 0,053 & 1\end{array}\right]$

3. matriks korelasi antar variabel sebagai berikut:

$\left[\begin{array}{cccccccc}1 & 0,057 & 0,297 & 0,161 & 0,274 & 0,340 & 0,081 & 0,213 \\ 0,057 & 1 & -0,036 & 0,042 & 0,155 & -, 004 & 0,017 & 0,111 \\ 0,297 & -0,036 & 1 & 0,107 & 0,189 & 0,276 & 0,268 & 0,326 \\ 0,161 & 0,042 & 0,107 & 1 & 0,074 & 0,148 & 0,127 & 0,033 \\ 0,274 & 0,155 & 0,189 & 0,074 & 1 & 0,281 & 0,247 & 0,355 \\ 0,340 & -0,004 & 0,276 & 0,148 & 0,281 & 1 & 0,156 & 0,355 \\ 0,081 & 0,017 & 0,268 & 0,127 & 0,247 & 0,156 & 1 & 0,220 \\ 0,213 & 0,111 & 0,326 & 0,033 & 0,355 & 0,355 & 0,220 & 1\end{array}\right]$

Nilai determinan pada masing-masing matriks tersebut mendekati nol, sehingga antar variabelnya terdapat korelasi.

\subsubsection{Uji Matriks Korelasi}

Uji Bartlett digunakan untuk menguji matriks korelasi apakah matriks tersebut merupakan matriks identitas atau bukan. Hasil uji Bartlett yang diperoleh untuk Indomie sebesar 107,735, Supermi sebesar 119,125 dan Sarimi sebesar 114,956. Sehingga matriks korelasi yang di uji pada masing-masing mie instan bukan merupakan matriks identitas.

\subsubsection{Penentuan Banyaknya faktor}


Tabel 3 : Loading Factors Indomie

\begin{tabular}{|c|c|c|c|c|c|c|c|}
\hline \multirow{2}{*}{ Variabel } & \multicolumn{7}{|c|}{ Loading Factors } \\
\cline { 2 - 8 } & \multicolumn{2}{|c|}{ Indomie } & \multicolumn{2}{|c|}{ Supermie } & \multicolumn{3}{c|}{ Sarimi } \\
\cline { 2 - 8 } & $\mathrm{F} 1$ & $\mathrm{~F} 2$ & $\mathrm{~F} 1$ & $\mathrm{~F} 2$ & $\mathrm{~F} 1$ & $\mathrm{~F} 2$ & $\mathrm{~F} 3$ \\
\hline Kualitas Mie & 0,395 & 0,623 & 0,492 & $-0,516$ & 0,598 & $-0,094$ & 0,286 \\
\hline Kuantitas Mie & 0,436 & $-0,433$ & 0,483 & 0,400 & 0,148 & $-0,865$ & 0,253 \\
\hline $\begin{array}{c}\text { Rasa dan } \\
\text { Bumbu }\end{array}$ & 0,656 & 0,188 & 0,665 & $-0,120$ & 0,622 & $-0,326$ & $-0,160$ \\
\hline Nutrisi & 0,294 & 0,179 & 0,436 & $-0,295$ & 0,290 & $-0,199$ & 0,823 \\
\hline Harga & 0,659 & $-0,291$ & 0,682 & 0,410 & 0,633 & 0,345 & $-0,109$ \\
\hline Kemasan & 0,549 & 0,424 & 0,501 & $-0,335$ & 0,662 & $-0,150$ & 0,045 \\
\hline Promosi & 0,508 & $-0,458$ & 0,392 & 0,565 & 0,482 & $-0,090$ & $-0,195$ \\
\hline $\begin{array}{c}\text { Kemudahan } \\
\text { memperoleh }\end{array}$ & 0,698 & $-0,060$ & 0,623 & $-0,102$ & 0,672 & 0,167 & $-0,320$ \\
\hline
\end{tabular}

Dari Tabel loading factors di atas menunjukan bahwa Indomie dan supermi merupakan besar korelasi antara suatu variabel dengan duafaktor yang terbentuk. Penentuan variabel mana yang akan masuk ke salah satu dari dua faktor dilakukan dengan cara membandingkan besar korelasi pada tiap baris. Sedangkan pada tabel loading factorsuntuk Sarimi merupakan besar korelasi antara suatu variabel dengan tiga faktor yang terbentuk. Penentuan variabel mana yang akan masuk ke salah satu dari tiga faktor dilakukan dengan cara membandingkan besar korelasi pada tiap baris.

\subsubsection{Komunalitas}

Komunalitas pada dasarnya adalah jumlah variansi dari suatu variabel mulamula yang bisa dijelaskan oleh faktor yang ada. Semakin besar komunalitas suatu variabel, maka semakin erat hubungan dengan faktor yang terbentuk (Santoso dalam Wijayanthy, S., 2005).

Tabel 4 : Komunalitas Indomie

\begin{tabular}{|c|c|c|c|}
\hline \multirow{2}{*}{ Variabel } & \multicolumn{3}{|c|}{ Komunalitas } \\
\cline { 2 - 4 } & Indomie & Supermie & Sarimi \\
\hline Kualitas Mie & 0,544 & 0,509 & 0,448 \\
\hline Kuantitas Mie & 0,387 & 0,393 & 0,834 \\
\hline Rasa dan Bumbu & 0,446 & 0,457 & 0,518 \\
\hline Nutrisi & 0,118 & 0,277 & 0,801 \\
\hline Harga & 0,519 & 0,633 & 0,532 \\
\hline Kemasan & 0,481 & 0,363 & 0,463 \\
\hline Promosi & 0,468 & 0,472 & 0,278 \\
\hline Kemudahan memperoleh & 0,491 & 0,399 & 0,518 \\
\hline
\end{tabular}


Dari ketiga tabel di atas hasil komunalitas untuk Indomie variabel kualitas mie memiliki nilai kom unalitas sebesar 0,544 yang artinya sekitar $54,4 \%$, Supermi sebesar 0,509 yang artinya sekitar $50,9 \%$ dan Sarimi sebesar 0,448 yang artinya sekitar $44,8 \%$.

\subsubsection{Total Variansi}

Total variansi adalah jumlah nilai eigen untuk variabel Indomie yang berjumlah 8. Total variansinya adalah $2,346+1,120+0,969+0,878+0,798+0,705+0,638+$ $0,546=8$. Faktor yang memiliki nilai eigen terbesar yaitu 2,346 adalah faktor yang paling dominan karena memiliki persentase variansi terbesar yaitu $29,324 \%$. Total variansi untuk Supermi adalah 2,364 +1,138+0,960+0,909+0,801+0,743+0,627 $+0,459=8$. Faktor yang memiliki nilai eigen terbesar yaitu 2,364 adalah faktor yang paling dominan karena memiliki persentase variansi terbesar yaitu $29,552 \%$. Dan total variansi untuk Sarimi adalah 2,373 + 1,080 + 1,003 +0,945+0,749+0,708+0,612= 8. Faktor yang memiliki nilai eigen terbesar yaitu 2,373 adalah faktor yang paling dominan karena memiliki persentase variansi terbesar yaitu $29,659 \%$.

\subsubsection{Hasil Rotasi Faktor}

Matriks faktor setelah rotasi dapat mempermudah interpretasi dalam menentukan variabel-variabel mana saja yang terdapat dalam suatu faktor. Metode rotasi yang digunakan adalah metode Orthogonal Varimax yang bertujuan untuk merotasi faktor yang telah diekstraksi sehingga pada akhirnya diperoleh hasil rotasi dimana suatu kolom nilai yang ada sebanyak mungkin mendekati nol (Marlina N, 2004).

Tabel 5 : Hasil Rotasi Indomie

\begin{tabular}{|c|c|c|c|c|c|c|c|}
\hline \multirow{2}{*}{ Variabel } & \multicolumn{6}{|c|}{ Loading Factors } \\
\cline { 2 - 8 } & \multicolumn{2}{|c|}{ Indomie } & \multicolumn{2}{c|}{ Supermie } & \multicolumn{3}{c|}{ Sarimi } \\
\cline { 2 - 8 } & $\mathrm{F} 1$ & $\mathrm{~F} 2$ & $\mathrm{~F} 1$ & $\mathrm{~F} 2$ & $\mathrm{~F} 1$ & $\mathrm{~F} 2$ & $\mathrm{~F} 3$ \\
\hline Promosi & 0,684 & 0,017 & $-0,062$ & 0,684 & 0,526 & 0,022 & $-0,037$ \\
\hline Harga & 0,678 & 0,243 & 0,259 & 0,752 & 0,590 & 0,042 & 0,426 \\
\hline Kuantitas Mie & 0,614 & $-0,014$ & 0,113 & 0,617 & $-0,044$ & 0,060 & 0,910 \\
\hline $\begin{array}{c}\text { Kemudahan } \\
\text { memperoleh }\end{array}$ & 0,548 & 0,437 & 0,543 & 0,322 & 0,725 & $-0,088$ & 0,219 \\
\hline Kualitas Mie & $-0,141$ & 0,724 & 0,708 & $-0,080$ & 0,443 & 0,496 & 0,077 \\
\hline Kemasan & 0,106 & 0,686 & 0,559 & 0,065 & 0,602 & 0,318 & $-0,014$ \\
\hline $\begin{array}{c}\text { Rasa dan } \\
\text { Bumbu }\end{array}$ & 0,347 & 0,588 & 0,587 & 0,335 & 0,662 & 0,164 & $-0,232$ \\
\hline Nutrisi & 0,090 & 0,332 & 0,524 & 0,053 & $-0,041$ & 0,894 & 0,026 \\
\hline
\end{tabular}

Dari Tabel 5 diperoleh hasil rotasi sebagai berikut: 
1. Rotasi Indomie $[(0,395)(0,726)+(0,623)(-0,688)]=-0,141$.

2. RotasiSupermie $[(0,492)(0,766)+(-0,516)(-0,642)]=0,708$.

3. RotasiSarimi $[(0,672)(0,915)+(0,167)(-0,092)+(-0,320)(-0,393])=0,725$.

\subsubsection{Interpretasi Faktor Setelah Rotasi}

Interpretasi faktor dilakukan untuk mempermudah dalam mengidentifikasi variabel yang mempunyai loading factors paling tinggi, hal ini menunjukkan pengaruh yang paling besar pada variabel asli.

Tabel 19 : Penamaan Faktor Untuk Indomie

\begin{tabular}{|c|c|c|c|}
\hline $\begin{array}{l}\text { Nama } \\
\text { produk }\end{array}$ & No. & Penamaan Faktor & Variabel \\
\hline \multirow{8}{*}{ Indomie } & \multirow{4}{*}{1.} & \multirow{4}{*}{ Faktor Eksternal Mie } & Promosi \\
\hline & & & Harga \\
\hline & & & Kuantitas Mie \\
\hline & & & Kemudahan Memperoleh \\
\hline & \multirow{4}{*}{2.} & \multirow{4}{*}{ Faktor Internal Mie } & Kualitas Mie \\
\hline & & & Kemasan \\
\hline & & & Rasa dan Bumbu \\
\hline & & & Nutrisi \\
\hline \multirow{8}{*}{ Supermie } & \multirow{5}{*}{1.} & \multirow{5}{*}{ Faktor Kualitas Produk Mie } & Kualitas Mie \\
\hline & & & Kemasan \\
\hline & & & Rasa dan Bumbu \\
\hline & & & Kemudahan Memperoleh \\
\hline & & & Nutris \\
\hline & \multirow{3}{*}{2.} & \multirow{3}{*}{ Faktor Strategi Pemasaran Mie } & Harga \\
\hline & & & Promosi \\
\hline & & & Kuantitas Mie \\
\hline \multirow{8}{*}{ Sarimi } & \multirow{5}{*}{1.} & \multirow{5}{*}{ Faktor Eksternal Mie } & Kemudahan Memperoleh \\
\hline & & & Rasa dan Bumbu \\
\hline & & & Kemasan \\
\hline & & & Harga \\
\hline & & & Promosi \\
\hline & \multirow{2}{*}{2.} & \multirow{2}{*}{ Faktor Internal Mie } & Nutrisi \\
\hline & & & Kualitas Mie \\
\hline & 3. & Faktor Kuantitas Mie & Kuantitas Mie \\
\hline
\end{tabular}

\subsubsection{Ketepatan Model Analisis Faktor}

Cara menguji ketepatan model yaitu dengan melihat jumlah residual antara matriks korelasi observasi dengan matriks korelasi reproduksi. Adapun cara mencari jumlah residual tersebut adalah sebagai berikut:

1. Jumlah residual Indomie

$$
\text { Residual } x_{1} x_{2}=\text { korelasi awal - korelasi yang dihasilkan }
$$




$$
\begin{aligned}
& =0,057-(-0,097) \\
& =0,154
\end{aligned}
$$

2. Jumlah residual Supermi

Residual $x_{1} x_{2}=$ korelasi awal - korelasi yang dihasilkan

$$
\begin{aligned}
& =0,106-(0,031) \\
& =0,075
\end{aligned}
$$

3. Jumlah residual Sarimi

Residual $x_{1} x_{2}=$ korelasi awal - korelasi yang dihasilkan

$$
\begin{aligned}
& =0,057-(0,080) \\
& =-0,023
\end{aligned}
$$

\subsection{Analisis Korespondensi}

\subsubsection{Uji Chi Square}

\begin{tabular}{|c|c|c|}
\hline $\begin{array}{l}\text { Faktor Mempengaruhi Pemilihan Produk Mie } \\
\qquad \text { Instan }\end{array}$ & $\begin{array}{l}\text { P-Value } \\
\left(x^{2}\right)\end{array}$ & $\begin{array}{c}\text { Nilai kritis } \\
\left(x^{2} \alpha d f(B-1)(k-1)\right.\end{array}$ \\
\hline Kualitas Mie & 18,657 & 15,507 \\
\hline Kuantitas Mie & 1,772 & 15,507 \\
\hline Rasa dan Bumbu & 27,967 & 15,507 \\
\hline Nutrisi & 4,588 & 15,507 \\
\hline Harga & 1,426 & 15,507 \\
\hline Kemasan & 5,760 & 15,507 \\
\hline Promosi & 6,684 & 15,507 \\
\hline Kemudahan Memperoleh & 7,375 & 15,507 \\
\hline
\end{tabular}

Uji chi-square digunakan Untuk mengetahui ada tidaknya hubungan antara dua variabel kategori dalam bentuk tabel kontingensi. Jika hipotesis nol diterima bila $x^{2}<$ nilai kritis dan sebaliknya jika hipotesis nol ditolak bila $x^{2}<$ nilai kritis (Anggraini, 2011).

Tabel 6 : Uji chi-square

Dari Tabel 6 dapat dilihat bahwa variabel kualitas mie dengan variabel rasa dan bumbu hipotesis nolnya ditolak karena $x^{2}<15.507$ berarti ada keterkaitan antara faktor-faktor yang mempengaruhi pemilihan produk mie instan. Sedangkan untuk variabel kuantitas mie, nutrisi, harga, kemasan, promosi, dan kemudahan memperoleh hipotesis nolnya diterima karena $\mathrm{x}^{2}>15,507$ berarti tidak ada hubungan antara faktorfaktor yang mempengaruhi pemilihan produk mie instan. Sehingga variabel kualitas mie serta variabel rasa dan bumbu dapat dilanjukan pada analisisis selanjutnya, yaitu analisis korespondensi untuk mengetahui pola hubungan variabel kualitas mie dan variabel rasa dan bumbu dengan produk mie instan melalui hasil plot.

\subsubsection{Tabel Kontingensi}


Tabel kontingensi disusun berdasarkan data hasil kuesioner hubungan antara faktor-faktor yang mempengaruhi pemilihan produk mie instan. Pada tabel kontingensi kategori baris merupakan mie instan dan kategori kolom merupakan alasan pemilihan produk mie instan yang dapat ditunjukan pada tabel sebagai berikut:

Tabel 7 : Kontingensi kualitas mie

\section{Correspondence Table}

\begin{tabular}{|l|l|l|l|l|l|l|}
\hline \multirow{2}{*}{ Mie_Instan } & \multicolumn{5}{l|}{ Kualitas_Mie } \\
\cline { 2 - 7 } & STB & TB & CB & B & SB & Active Margin \\
\hline Indomie & 2 & 2 & 17 & 72 & 42 & 135 \\
Supermi & 2 & 3 & 26 & 76 & 28 & 135 \\
Sarimi & 1 & 4 & 40 & 69 & 21 & 135 \\
Active Margin & 5 & 9 & 83 & 217 & 91 & 405 \\
\hline
\end{tabular}

Tabel 8 : kontingensi Rasa dan Bumbu

Correspondence Table

\begin{tabular}{|l|l|l|l|l|l|l|}
\hline \multirow{2}{*}{ Mie_Instan } & \multicolumn{5}{l|}{ Rasa_dan_bumbu } \\
\cline { 2 - 7 } & STB & TB & CB & B & SB & Active Margin \\
\hline Indomie & 4 & 3 & 31 & 68 & 29 & 135 \\
Supermi & 4 & 6 & 42 & 63 & 20 & 135 \\
Sarimi & 1 & 10 & 64 & 45 & 15 & 135 \\
Active Margin & 9 & 19 & 137 & 176 & 64 & 405 \\
\hline
\end{tabular}

\subsubsection{Pola hubungan antara Pemilihan Produk Mie Instan Dengan Kualitas Mie}

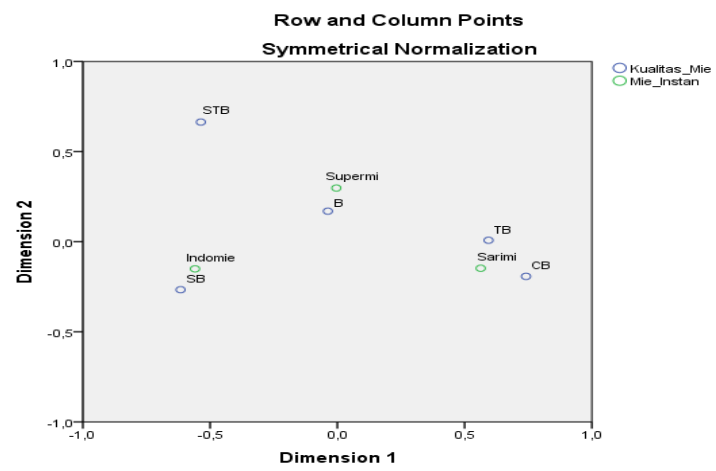

Gambar 1 : Plot Analisis Korespondensi Produk Mie Instan Dengan Kualitas Mie.

Dari tampilan plot hasil korespondesi pada gambar 1 terlihat produk mie Indomie mem punyai jarak sangat dekat dengan SB (sangat baik), produk mie supermi mempunyai jarak sangat dekat dengan B (baik). Sedangkan produk mie sarimi mempunyai jarak sangat dekat dengan $\mathrm{CB}$ (cukup baik) dan TB (tidak baik). Sehingga bisa dijelaskan menurut presepsi para konsumen dalam penelitian ini, produk mie instan Indomie dan Supermi memiliki kualitas mie yang sangat baik. Hal ini 
membuktikan bahwa produk mie instan Indomie dan Supermi ini memiliki kekenyalan yang enak dan mempunyai rasa tidak terlalu mengganggu. Sedangkan produk mie instan Sarimi, konsumen menganggap kualitas mie yang dimiliki produk mie instan Sarimi biasa saja.

3.3.4. Pola hubungan antara Pemilihan Produk Mie Instan Dengan Rasa dan bumbu

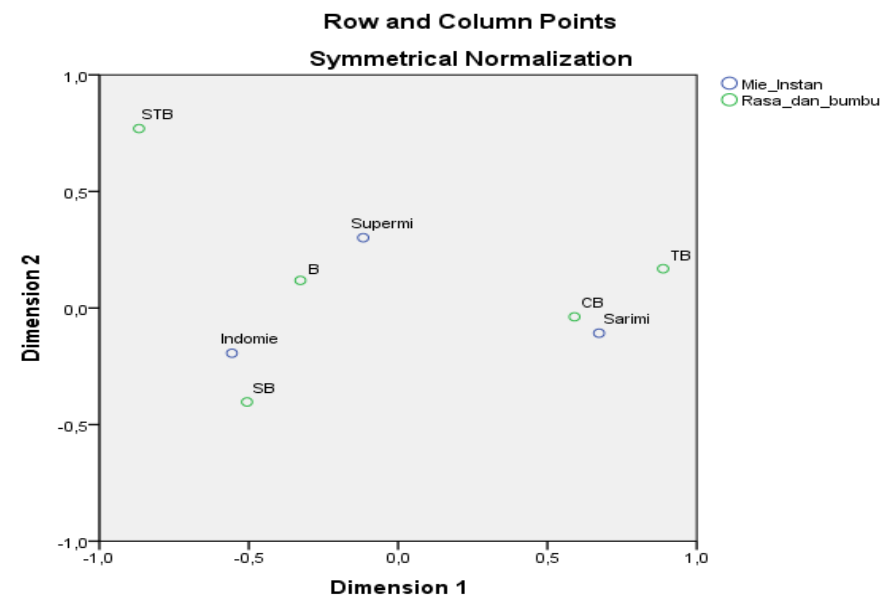

Gambar 2 : Plot Analisis Korespondensi Produk Mie Instan Dengan Rasa dan Bumbu

Pada plot analisis korespondensi produk mie instan dengan rasa dan bumbu dapat dilihat pada gambar 2 di atas terlihat produk mie Indomie mempunyai jarak cukup dekat dengan SB (sangat baik), produk mie supermi mempunyai jarak cukup dekat dengan B (baik). Sedangkan produk mie sarimi mempunyai jarak sangat dekat dengan CB (cukup baik) dan mempunyai jarak cukup dekat dengan TB (tidak baik). Sehingga bisa dijelaskan menurut presepsi para konsumen dalam penelitian ini, produk mie instan Indomie dan Supermi memiliki rasa dan bumbu yang sangat baik. Hal ini membuktikan bahwa produk mie instan Indomie dan Supermi ini mempunyai rasa bervariasi (kaya rasa), aroma yang mengundang selera, dan memiliki bumbu tambahan serta pelengkap. Sedangkan produk mie instan Sarimi, konsumen menganggap rasa dan bumbu yang dimiliki produk mie instan Sarimi biasa saja. 


\section{KESIMPULAN}

Berdasarkan hasil analisis data yang telah dilakukan, maka diperoleh kesimpulan sebagai berikut:

1. Faktor-faktor yang mempengaruhi konsumen dalam pemilihan produk mie instan adalah:

a. Faktor-faktor yang mempengaruhi pemilihan mie Instan Indomie terdapat 2 faktor terbentuk yaitu:

$>\quad$ Faktor Eksternal Mie dengan nilai eigen 2,346 yang terdiri dari empat variabel yaitu promosi, harga, kuantitas mie dan kemudahan memperoleh.

$>\quad$ Faktor Internal Mie dengan nilai eigen 1,120 yang terdiri dari empat variabel yaitu kualitas mie, kemasan, rasa dan bumbu, serta nutrisi.

b. Faktor-faktor yang mempengaruhi pemilihan mie Instan Supemi terdapat 2 faktor terbentuk adalah:

$>\quad$ Faktor Kualitas Produk Mie dengan nilai eigen 2,364 yang terdiri dari lima variabel yaitu kualitas mie, kemasan, rasa dan bumbu, kemudan memperoleh dan nutrisi.

$>\quad$ Faktor Strategi Pemasaran Mie dengan nilai eigen 1,138 yang terdiri dari tiga variabel yaitu harga, promosi dan kuantitas mie.

c. Faktor-faktor yang mempengaruhi pemilihan mie Instan Sarimi terdapat 3 faktor terbentuk adalah:

$>\quad$ Faktor Eksternal Mie dengan nilai eigen 2,373 yang terdiri dari lima variabel yaitu haga, rasa dan bumbu, kemasan, harga, serta promosi.

$>\quad$ Faktor Internal Mie dengan nilai eigen 1,080 yang terdiri dari dua variabel yaitu nutrisi dan kualitas mie.

$>\quad$ Faktor Kuantitas Mie dengan nilai eigen 1,003 yang terdiri dari satu variabel yaitu kuantitas mie.

2. Variabel Indomie dan sarimi merupakan faktor yang paling dominan yang berpengaruh dalam pemilihan produk mie instan untuk faktor ekternal mie. Sedangkan variabel supermi merupakan faktor yang paling dominan yang berpengaruh dalam pemilihan produk mie instan untuk faktor kualitas produk mie karena masing-masing mempunyai nilai eigen terbesar.

3. Dari 8 variabel yang memiliki keterkaitan antara faktor-faktor yang mempengaruhi pemilihan produk mie instan adalah variabel kualitas mie serta variabel rasa dan bumbu karena mempunyai nilai Chi-Square lebih besar dari nilai kritis. Kedua variabel tersebut dapat dilanjukan pada analisis korespondensi untuk mengetahui pola hubungan variabel kualitas mie dan variabel rasa dan bumbu dengan produk mie instan melalui hasil plot. Sedangkan untuk variabel kuantitas mie, nutrisi, harga, kemasan, promosi, dan kemudahan tidak ada keterkaitan antara faktor-faktor yang mempengaruhi pemilihan produk mie instan karena mempunyai nilai Chi-Squarelebih kecil dari nilai kritis, sehingga tidak dapat dilanjukan pada analisis korespondensi. 
4. Pola hubungan antara faktor-faktor yang mem pengaruhi pemilihan produk mie instan seperti Indomie dan Supermi yaitu memiliki kualitas mie serta rasa dan bumbu yang sangat baik. hal ini membuktikan bahwa keduanya memiliki kekenyalan mie yang enak dan mempunyai rasa mie tidak terlalu mengganggu. Selain itu keduanya mempunyai rasa bervariasi (kaya rasa), aroma yang mengundang selera, dan memiliki bumbu tambahan serta pelengkap. Sedangkan untuk produk mie instan sarimi baik dari kualitas mie maupun rasa dan bumbunya memiliki kualitas mie serta rasa dan bumbu biasa saja.

\section{DAFTAR PUSTAKA}

[1] Anggraini, Analisis Korespondensi Hubungaan Antara Kondisi Sekolah, Tenaga Pengajardan Sarana Belajar Terhadap Prestasi Sekolah: Studi Kasus SMA \& SMK Jakarta Selatan 2010), Universitas Islam Negeri Syafir Hidayatullah, (Online), 2011, (http://repository.uinjkt.ac.id/dspace/bitstream/123456789/4825/1/Anggraini-FST.pdf), diakses 18 September 2014.

[2] Marlina, N., Faktor-faktor Keharmonisan Perkawinan Ditinjau Dari Respon Istri Pada Pegawai Wanita di BPS Pusat Tahun 2004, STIS, Jakarta.

[3] Pukuh, N., Gambaran Perbandingan Persepsi Konsumen Terhadap Produk Mie Instan Merek Indomie, Supermi dan Mie Sedap, 2007, Jurusan Statistika, Sekolah Tinggi IImu Statistika, Jakarta.

[4] Riduwan dan Kuncoro, E.A., Cara Menggunakan dan Memaknai Analisis Jalur (Path Analisis), Alfabeta, 2007, Bandung.

[5] Wijayanthy, S., Faktor-faktor Penyebab Keterlambatan Waktu Pembangunan Proyek Gedung Negara Di Lingkungan Pemerintahan Kota Kediri, (Online), 2005, (http://www.mmt.its.ac.id), diakses 10 Oktober 2014. 